\title{
UPAYA PENINGKATAN KUALITAS PELAYANAN PADA TOKO BANGUNAN UD SUMBER WANGI DENGAN INTEGRASI SERVICE QUALITY DAN QUALITY FUNCTION DEPLOYMENT (Studi kasus : UD. Sumber Wangi)
}

\author{
Rifqi Dhiaul Firdaus ${ }^{\text {I) }}$, Nina Aini Mahbubah ${ }^{2)}$, Elly Ismiyah ${ }^{3)}$ \\ ${ }^{1}$ Mahasiswa Teknik Industri, Fakultas Teknik, Universitas Muhammadiyah Gresik \\ ${ }^{2,3}$ Dosen Teknik Industri, Fakultas Teknik, Universitas Muhammadiyah Gresik \\ J1. Sumatera No. 101 GKB - Gresik 61121 \\ e-mail : $\underline{\text { dzerteagle27@gmail.com }}$
}

\begin{abstract}
ABSTRAK
UD. Sumber Wangi merupakan suatu usaha jasa yang melayani penjualan barang material bangunan. Badan usaha ini mengalami masalah berupa pelayanan yang kurang baik, ditandai dengan beberapa keluhan pelanggan dan juga perginya pelanggan yang memilih toko lain. Pada penelitian ini akan dilakukan perbaikan kualitas pelayanan dengan metode service quality dan juga diintegrasikan dengan metode quality function deployment. Tahapan penelitian ini diawali dengan membagikan kuesioner kepada pelanggan. Dari kuesioner itu akan diolah dengan metode service quality sehingga dapat diketahui mana atribut pelayanan yang memiliki nilai negatif dan masih belum memenuhi kepuasan pelanggan. Dari atribut dengan nilai negatif inilah selanjutnya diolah dengan metode quality function deployment. Pada metode QFD terdapat berbagai perhitungan matematis dan nantinya dapat dibuat suatu house of quality. Pada HOQ ini terdapat respon teknis yang berisi jawaban atas masalah kualitas pelayanan yang terjadi pada UD. Sumber Wangi. Dari penelitian ini akan diketahui mana atribut layanan yang memiliki nilai gap negatif terbesar yaitu kebersihan ruang tunggu dengan nilai $-1,43$. Sementara atribut dengan gap negatif terkecil adalah keteraturan antrian pelayanan dengan nilai $-0,02$. Sementara pada pengolahan data QFD, pada house of quality, respon teknis dengan nilai tertinggi adalah penambahan jumlah dan kelengkapan barang material dengan nilai relative weight and percent sebesar 163.200. Diikuti dengan penambahan sarana hiburan dengan nilai sebesar 140.232. Dari penelitian ini dapat disimpulkan bahwa penerapan metode servqual sangat berperan dalam menentukan langkah pada metode QFD sehingga respon teknis dapat diterima dengan hasil baik. Sebagai saran untuk perusahaan adalah agar segera menerapkan respon teknis tersebut demi keberlangsungan usaha.
\end{abstract}

Kata kunci : Service Quality, Quality Function Deployment, House of Quality, Relative Weight and Percent

\section{PENDAHULUAN}

Seiring bergulirnya perdagangan bebas dalam persaingan berskala global, maka masalah kualitas merupakan salah satu bagian penting dan sangat perlu mendapat perhatian yang serius bagi setiap perusahaan untuk tetap bisa bertahan dalam lingkungan bisnis. Bagi setiap perusahaan, baik yang bergerak dalam industri manufaktur maupun industri jasa pelayanan yang berkualitas merupakan tuntutan pelanggan yang harus dipenuhi. Terciptanya kualitas layanan tentunya akan menciptakan kepuasan pelanggan, yang pada akhirnya dapat memberikan beberapa manfaat diantaranya terjalin hubungan yang harmonis antara penyedia barang ataupun jasa dengan pelanggan, memberikan dasar yang baik bagi loyalitas pelanggan dan membentuk suatu rekomendasi dari mulut ke mulut yang menguntungkan bagi penyedia jasa tersebut (Wijaya, 2016).

UD.Sumber Wangi adalah sebuah UKM toko bangunan yang beralamat di JL. KH. Syafii 115, Desa Suci, Kecamatan Manyar, Kabupaten Gresik. Toko ini berdiri sejak tahun 2000, dan

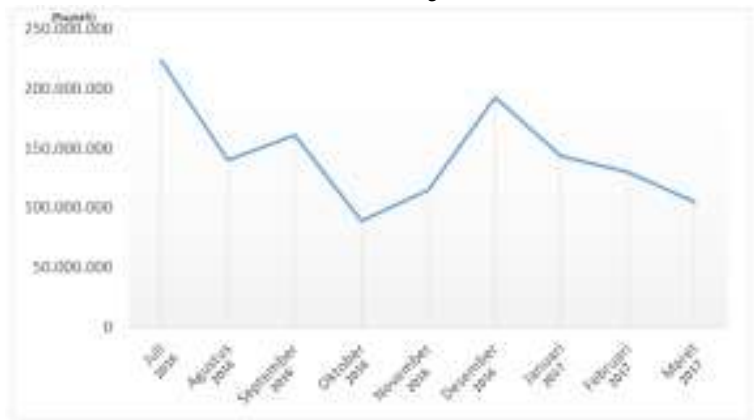


merupakan toko bangunan pertama yang ada di desa Suci. Seiring berjalannya waktu, toko ini terus mendapat pelanggan, ada yang dari konsumen perorangan, ada pula yang dalam bentuk usaha proyek, dan juga ada yang berasal dari institusi tertentu seperti sekolah dan pondok pesantren. Sebagai toko bangunan, UD Sumber Wangi tentu terus mendapat pesaing dari toko lain yang jumlahnya terus bertambah. Hal ini tentu mengakibatkan para konsumen menjadi memiliki banyak alternatif pilihan untuk memilih toko bangunan yang cocok dengan kepuasannya. Para konsumen akan cenderung memilih toko bangunan yang memiliki kualitas pelayanan yang lebih baik. Dalam pelayanan UD. Sumber Wangi sendiri masih terlihat terdapat beberapa pelayanan yang masih belum maksimal. Salah satunya adalah antrian yang panjang dan kurang teratur, yang bisa diakibatkan kurangnya jumlah pelayan yang ada. Di samping itu, kualitas sumber daya manusia juga berpengaruh kuat terhadap jaminan pelayanan yang diberikan. Sementara itu, pada saat jam sibuk toko, para konsumen lebih memilih untuk berdiri karena tempat duduk yang kotor. Kondisi ruang tunggu yang kurang bersih juga sangat berpengaruh terhadap kepuasan pelanggan. Apabila pelanggan merasa kecewa dengan pelayanan yang diberikan pihak toko dampaknya secara langsung dapat menurunkan omzet pendapatan yang didapat UD Sumber Wangi. Masalah omzet yang fluktuatif harus segera ditangani, karena masalah ini memiliki dampak jangka panjang bagi keberlangsungan perusahaan. Berikut adalah data pendapatan omzet pada UD Sumber Wangi pada bulan Juli tahun 2018 hingga bulan Maret 2019 yang diperoleh dari pembukuan yang dilakukan administrasi toko.

Gambar 1 Chart omzet penjualan UD Sumber Wangi Peruide Juli 2016 Maret 2017

Dari fenomena yang terjadi mengenai omzet yang fluktuatif tersebut, dapat disebabkan karena berbagai faktor. Salah satunya adalah Kualitas pelayanan UD Sumber Wangi yang secara langsung dapat berpengaruh terhadap kepuasan pelanggan. Dengan kualitas pelayanan yang buruk, konsumen akan kecewa dan memilih toko lain. Kekecewaan konsumen sering terjadi dan biasanya disampaikan langsung kepada bagian administrasi toko.

\section{A. Rumusan Masalah}

Berdasarkan uraian yang sudah dikemukakan pada latar belakang masalah diatas, maka dapat disimpulkan perumusan masalah pada penelitian ini adalah "Bagaimana upaya yang tepat dalam meningkatkan kepuasan pelanggan berdasarkan analisis kualitas pelayanan UD. Sumber Wangi dengan integrasi metode servqual dan QFD?"

\section{B. Tujuan Penelitian}

Adapun tujuan penelitian yang ingin dicapai adalah sebagai berikut :

1. Mengidentifikasi atribut-atribut yang berperan dalam menentukan tingkat kepuasan pelanggan menurut 5 dimensi servqual.

2. Menghitung data tentang tingkat kepuasan, kepentingan, dan harapan pelanggan terhadap atribut pelayanan yang diberikan UD Sumber Wangi.

3. Menganalisis nilai gap pada masingmasing atribut kualitas pelayanan UD Sumber Wangi berdasarkan perhitungan pada metode servqual.

4. Membuat rancangan pelayanan sebagai evaluasi kesesuaian terhadap keinginan dan kebutuhan pelanggan dengan penerapan model HOQ pada metode QFD.

\section{TINJAUAN PUSTAKA}

\section{A. Usaha Mikro Kecil Menengah}

Terdapat beberapa definisi dasar yang menjelaskan tentang usaha mikro, kecil, dan menengah. Definisi UMKM menurut UndangUndang No. 20 Tahun 2008 tentang Usaha Mikro, Kecil dan Menengah Bab 1 Pasal 1: Usaha mikro adalah usaha produktif milik orang perorangan dan atau badan usaha perorangan yang memenuhi kriteria usaha mikro. Usaha kecil adalah usaha produktif yang berdiri sendiri, yang 
dilakukan oleh perseorangan atau badan usaha bukan merupakan anak cabang perusahaan yang dimiliki, dikuasai, atau menjadi bagian baik langsung maupun tidak langsung dari usaha menengah atau besar yang memenuhi kriteria usaha kecil.

Sedangkan usaha menengah adalah usaha ekonomi produktif yang berdiri sendiri, yang dilakukan oleh orang perorangan atau badan usaha yang bukan merupakan anak perusahaan atau cabang perusahaan yang dimiliki, dikuasai, atau menjadi bagian baik langsung maupun tidak langsung dengan Usaha kecil atau Usaha besar dengan jumlah kekayaan bersih atau hasil penjualan tahunan.

\section{B. Uji Validitas Dan Reliabilitas}

Menurut Djamaludin (1989) validitas berasal dari kata validity yang mempunyai arti sejauh mana ketepatan dan kecermatan suatu alat ukur dalam melakukan fungsi ukurnya. Suatu skala atau instrumen pengukur dapat dikatakan mempunyai validitas yang tinggi apabila instrumen tersebut menjalankan fungsi ukurnya, atau memberikan hasil ukur yang sesuai dengan maksud dilakukannya pengukuran tersebut. Sedangkan tes yang memiliki validitas rendah akan menghasilkan data yang tidak relevan dengan tujuan pengukuran.Terkandung di sini pengertian bahwa ketepatan validitas pada suatu alat ukur tergantung pada kemampuan alat ukur tersebut mencapai tujuan pengukuran yang dikehendaki dengan tepat.

Menurut Masri Singarimbun (1989), realibilitas adalah indeks yang menunjukkan sejauh mana suatu alat ukur dapat dipercaya atau dapat diandalkan. Bila suatu alat pengukur dipakai dua kali - untuk mengukur gejala yang sama dan hasil pengukuran yang diperoleh relative konsisten, maka alat pengukur tersebut reliable. Dengan kata lain, realibitas menunjukkan konsistensi suatu alat pengukur di dalam pengukur gejala yang sama. Reliabilitas, atau keandalan, adalah konsistensi dari serangkaian pengukuran atau serangkaian alat ukur. Hal tersebut bisa berupa pengukuran dari alat ukur yang sama (tes dengan tes ulang) akan memberikan hasil yang sama, atau untuk pengukuran yang lebih subjektif, apakah dua orang penilai memberikan skor yang mirip (reliabilitas antar penilai).

\section{Service Quality}

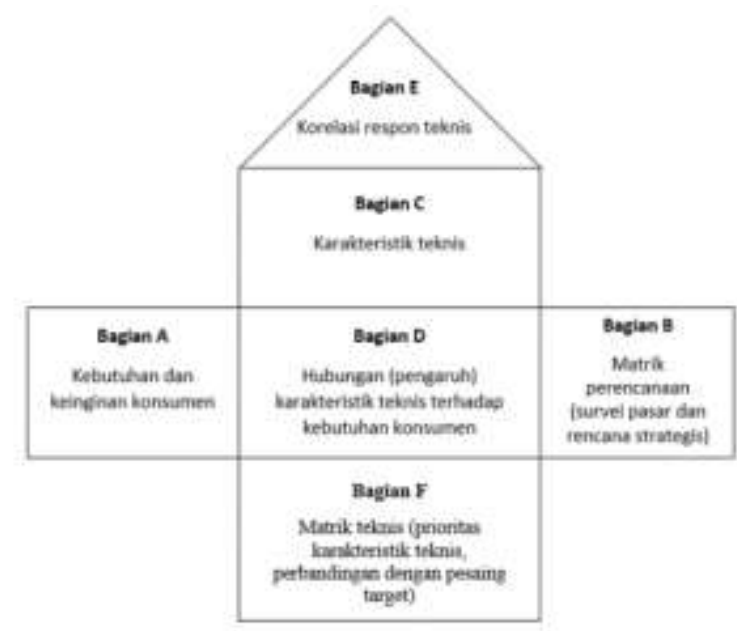

Service Quality adalah metode untuk mengetahui kualitas layyanan berdasarkan hasil kesenjangan gap, yaitu bagaimana persepsi pelanggan dan harapan pelanggan terhadap pelayanan yang diberikan kepada pelanggan UD Sumber Wangi. Di dalam metode ini terdapat proses analisa yang ringkas namun memiliki akurasi dan kebenaran yang cukup tinggi yang dapat manajemen perusahaaan gunakan agar lebih mengerti bagaimana persepsi konsumen dan harapan konsumen terhadap pelayanan yang diberikannya. Setiap pelanggan tentunya memiliki tingkat kepuasan yang berbeda dengan pelanggan lain. Tingkat kepuasan ini disebut juga sebagai harapan pelanggan (customer expectation) yang memainkan peranan penting sebagai perbandingan dalam mengevaluasi kualitas maupun kepuasan pelanggan. Konsep servqual digunakan untuk menghitung gap antara persepsi pelanggan terhadap jasa yang dikurangi dengan nilai ekspektasi atau harapan pelanggan (expected service). Apabila jasa yang diterima (perceived service) melebihi yang diharapkan (expected service) maka kualitas jasa dipersepsikan baik dan memuaskan. Sebaliknya bila jasa dipersepsikan lebih rendah daripada yang diharapkan, maka kualitas jasa dipersepsikan buruk atau tidak memuaskan. 


\section{Quality Function Deployment}

Konsep quality function deployment (QFD) dikembangkan untuk menjamin bahwa kualitas jasa berada pada kualitas yang baik. Konsep ini pertama kali dikembangkan di perusahaan Mitsubishi Kobe Shipyard di Jepang. Teknik ini timbul dari teknik manajemen mutu terpadu. Istilah QFD timbul dari gagasan bahwa mutu berarti menghasilkan kepuasan pelanggan dan tugas pengembangan mutu adalah menciptakan atau menyebarkan kualitas yang baik.(Wijaya, 2016). Adapun Daets Bernard (1982) mendefinisikan QFD sebagai proses perencanaan sistematis yang dikembangkan untuk membantu tim proyek menyusun semua elemen yang dibutuhkan untuk mendefinisikan, mendesain, dan menghasilkan produk atau jasa yang dapat memenuhi kebutuhan pelanggan. Alat yang digunakan untuk menggunakan struktur QFD adalah matrik yang berbentuk rumah, yang disebut house of quality. Bentuk dan keterangan dari setiap bagian matrik house of quality adalah tampat pada gambar berikut. (Wijaya, 2016)

\section{Gambar 2 Model house of quality}

\section{METODOLOGI PENELITIAN} Metodologi penelitian $\begin{array}{r}\text { merupakan } \\ \text { keseluruhan }\end{array}$
gambaran penelitian secara
sehingga dapat diketahui proses, metode, dan
hasil yang diperoleh dari penelitian ini. Obyek
dalam penelitian ini adalah kualitas pelayanan
pada UD. Sumber Wangi

Penelitian ini dimulai dengan survei pendahuluan untuk mengidentifikasi permasalahan yang terjadi kemudian dilakukan perumusan masalah dan penentuan tujuan penelitian setelah itu dilakukan studi literatur dan studi lapangan untuk mengetahui dengan jelas permasalahan yang terjadi dan langkah penyelasianya. Pada penelitian ini penyelesaian permasalahan menggunakan metode servqual dan QFD. Pada tahap awal dimulai dengan menerapkan metode servqual dengan membagikan kuesioner kepada konsumen untuk

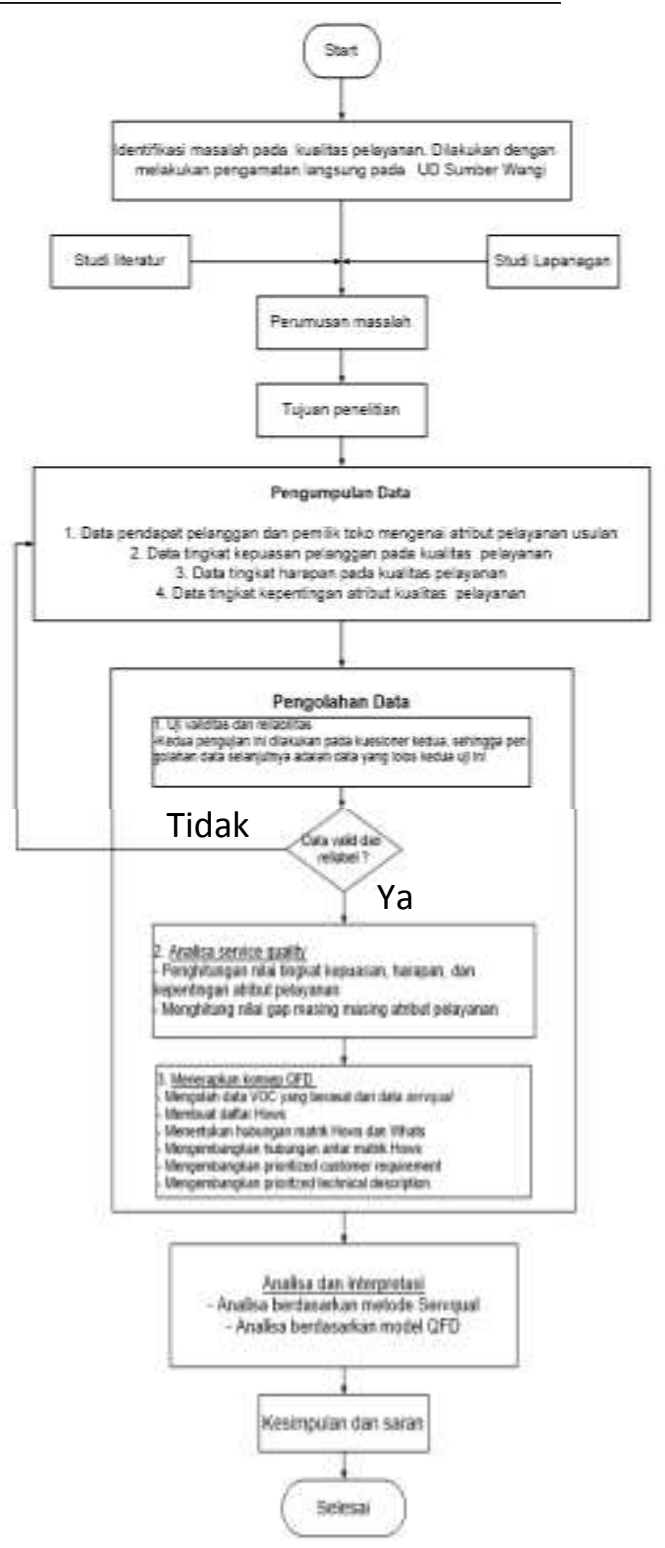

mengetahui tingkat persepsi dan harapan dari pelayanan yang diberikan UD. Sumber Wangi. Selanjutnya data servqual diolah dengan metode QFD untuk mengetahui solusi dari permasalahan ketidakpuasan pelanggan akan pelayanan yang diberikan. Agar lebih jelas, kerangka berfikir dalam penelitian ini dapat dilihat pada gambar 3 .

Gambar 3 Flowchart Penelitian

IV. HASIL DAN PEMBAHASAN 


\section{Analisis Service Quality}

Dari penyebaran kuesioner, terdapat 28 atribut pelayanan yang diteliti. Didalam konsep servqual, atribut pelayanan dikatakan tidak memenuhi kebutuhan konsumen bila atribut tersebut memiliki gap negatif. Berikut adalah penjelasan masing masing atribut berdasarkan konsep servqual.

\section{Dimensi Reliability}

Dari pengolahan data dengan konsep servqual, maka dapat dilakukan analisis sebagai berikut.

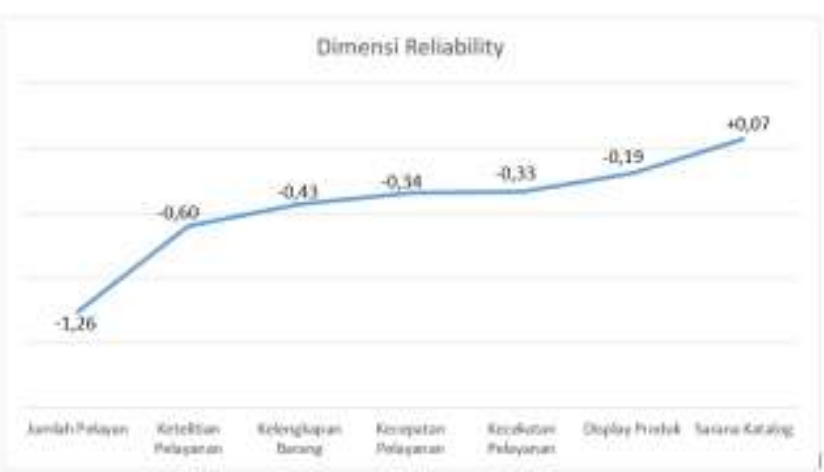

Gambar 4 Diagram garis nilai gap dimensi reliability

Dari diagram garis diatas maka dapat diketahui mana atribut pelayanan yang sudah memenuhi kebutuhan konsumen dan yang belum. Dimensi reliability dalam penelitian ini terdiri dari 7 atribut pelayanan. Terdapat 1 atribut pelayanan yang memiliki gap positif dan sudah berhasil memuaskan pelanggan berdasarkan konsep servqual, yaitu atribut pelayanan mengenai sarana brosur dan katalog produk dengan nilai gap $+0,07$. Sedangkan untuk 6 atribut pelayanan lainnya memiliki gap negatif dan belum memenuhi kepuasan konsumen. Atribut pelayanan dengan gap terbesar adalah pada jumlah pelayan. Atribut ini memiliki gap 1,26 .

\section{Dimensi Responsiveness}

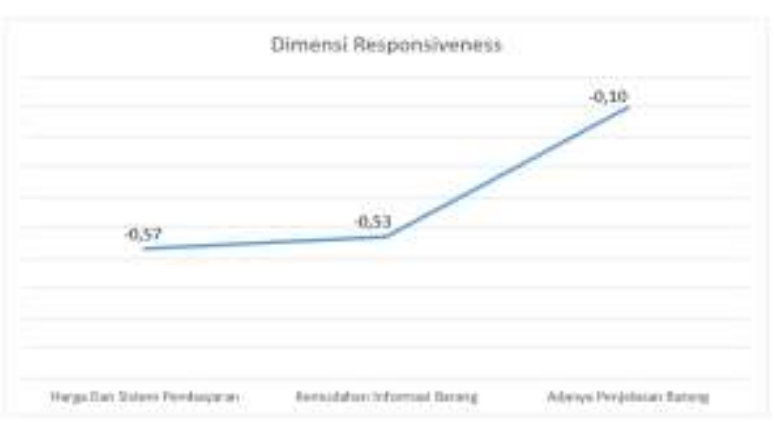

Dari pengolahan data dengan konsep servqual, maka dapat dilakukan analisis sebagai berikut.

Gambar 5. Diagram garis nilai gap rimensi responsiveness

Dimensi responsiveness dalam penelitian ini terdiri dari 3 atribut pelayanan. Dari ke 4 atribut pelayanan tersebut semuanya memiliki gap negatif. Atribut pelayanan dengan gap negatif terbesar adalah pada harga dan sistem pembayaran pada UD. Sumber Wangi yang bernilai gap $-0,57$

\section{Dimensi Assurance}

Dari pengolahan data dengan konsep servqual, maka dapat dilakukan analisis sebagai berikut.

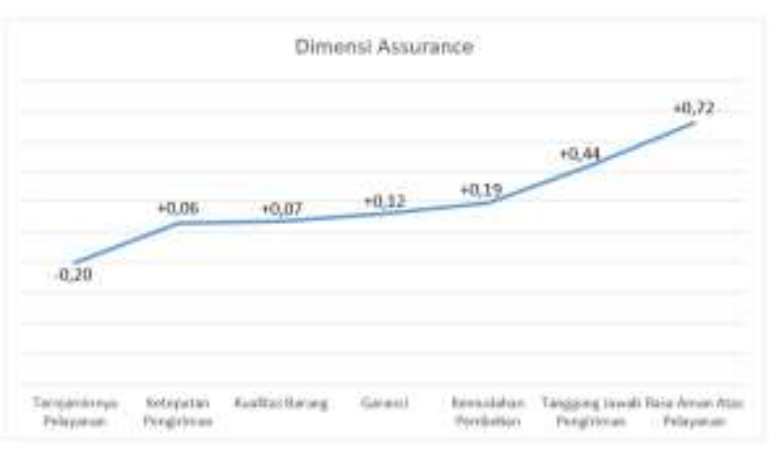

Gambar 6. Diagram garis nilai gap rimensi assurance

Dimensi assurance dalam penelitian ini terdiri dari 7 atribut pelayanan. Dari ke 7 atribut pelayanan tersebut hanya terdapat 1 atribut pelayanan yang memiliki gap negatif, yakni atribut pelayanan terjaminnya kualitas pelayanan dengan nilai $-0,20$. Sedangkan atribut pelayanan 
dengan nilai gap positif tertinggi adalah perasaan aman dalam pelayanan yang diberikan toko dengan nilai $+0,72$

\section{Dimensi Emphaty}

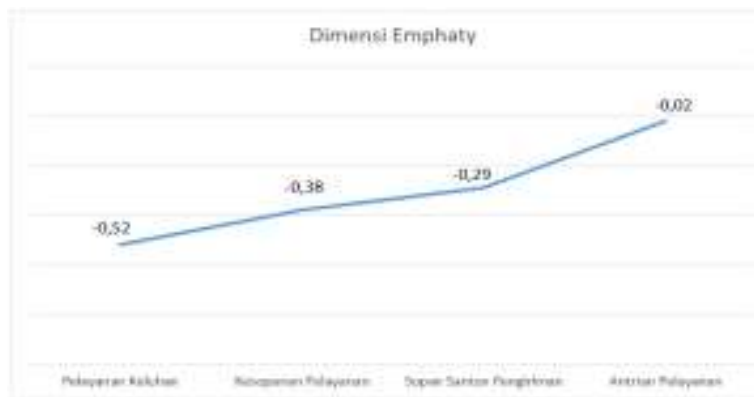

Gambar 7 Diagram garis nilai gap rimensi emphaty

Dimensi emphaty dalam penelitian ini terdiri dari 4 atribut pelayanan. Dari penerapan konsep perhitungan servqual, keseluruhan atribut pelayanan memiliki gap negatif. Atribut pelayanan dengan gap negatif terbesar adalah pada ketepatan menanggapi keluhan dan saran, dengan nilai gap $-0,52$.

\section{Dimensi Tangible}

Dari pengolahan data dengan konsep servqual, maka dapat dilakukan analisis sebagai berikut.

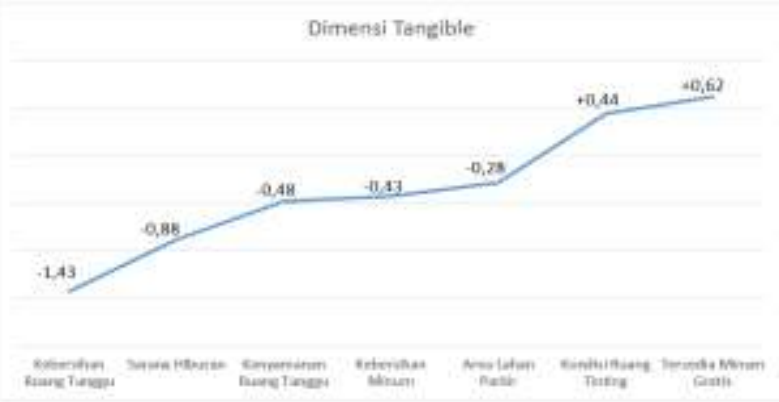

Gambar 8 Diagram garis nilai gap rimensi tangible

Dimensi tangible dalam penelitian ini terdiri dari 7 atribut pelayanan. Dari ke 7 atribut pelayanan tersebut, terdapat 5 atribut pelayanan dengan gap negatif, dan 2 atribut layanan dengan gap positif. Atribut pelayanan dengan gap positif adalah tersedianya minuman gratis dengan nilai gap +0,62 dan kondisi ruangan mesing tinting cat dengan nilai gap $+0,44$. Sedangkan untuk atribut pelayanan dengan nilai gap negatif terbesar adalah pada kebersihan ruang tunggu yang memiliki nilai gap $-1,43$

Dari ke-5 dimensi servqual tersebut, dapat dilihat bahwa total terdapat 9 atribut pelayanan dengan nilai gap positif dan 19 atribut pelayanan dengan nilai gap negatif. Atribut pelayanan dengan nilai gap positif terbesar adalah pada dimensi assurance mengenai perasaan aman dalam pelayanan yang diberikan selama di toko dengan nilai $+0,72$. Sedangkan atribut pelayanan dengan nilai gap negatif terbesar adalah pada dimensi tangible mengenai kebersihan ruang tunggu dengan nilai gap sebesar $-1,43$.

\section{Analisis Quality Function Deployment}

Pada penerapan metode QFD hal utama yang diteliti adala suara pelanggan atau voice of customer. Didalam penelitian ini mengintegrasikan 2 metode yakni metode servqual dan QFD. Sehingga pada voice of customer dalam QFD diisi atribut pelayan dengan nilai gap negatif yang berasal dari konsep servqual. Dan setelah melihat seluruh atribut pelayanan, dapat ditentukan respon teknis yang berasal dari diskusi dengan pihak toko, dan konsumen. Berikut adalah respon teknisnya.

\section{Tabel 1 Respon Teknis}

\begin{tabular}{|l|l|}
\hline No & Respon Teknis \\
\hline 1 & $\begin{array}{l}\text { Pelatihan dan rekrutmen pekerja } \\
\text { yang tepat }\end{array}$ \\
\hline 2 & $\begin{array}{l}\text { Penerapan jadwal piket kebersihan } \\
\text { bagi setiap pekerja }\end{array}$ \\
\hline 3 & $\begin{array}{l}\text { Menambah jumlah dan kelengkapan } \\
\text { barang material }\end{array}$ \\
\hline 4 & $\begin{array}{l}\text { Menambah sarana hiburan seperti } \\
\text { musik dan tv }\end{array}$ \\
\hline 5 & $\begin{array}{l}\text { Pengolahan kotak saran yang } \\
\text { dilakukan lebih rutin }\end{array}$ \\
\hline 6 & $\begin{array}{l}\text { Penyesuaian harga dan sistem } \\
\text { pembayaran barang material }\end{array}$ \\
\hline
\end{tabular}


Vol. 1, No. 4, 2020

\begin{tabular}{|l|l|}
\hline 7 & Penerapan tata letak layout fasilitas \\
\hline
\end{tabular} yang lebih baik

Dan setelah melalui seluruh perhitungan dari metode QFD maka didapatlah model House of Quality. HOQ bisa dibuat setelah memberikan angka korelasi antar matrik whats dan matrik hows, perhitungan-perhitungan lain seperti tingkat kepentingan, target value, dan sales point. Berikut adalah model HOQ nya.

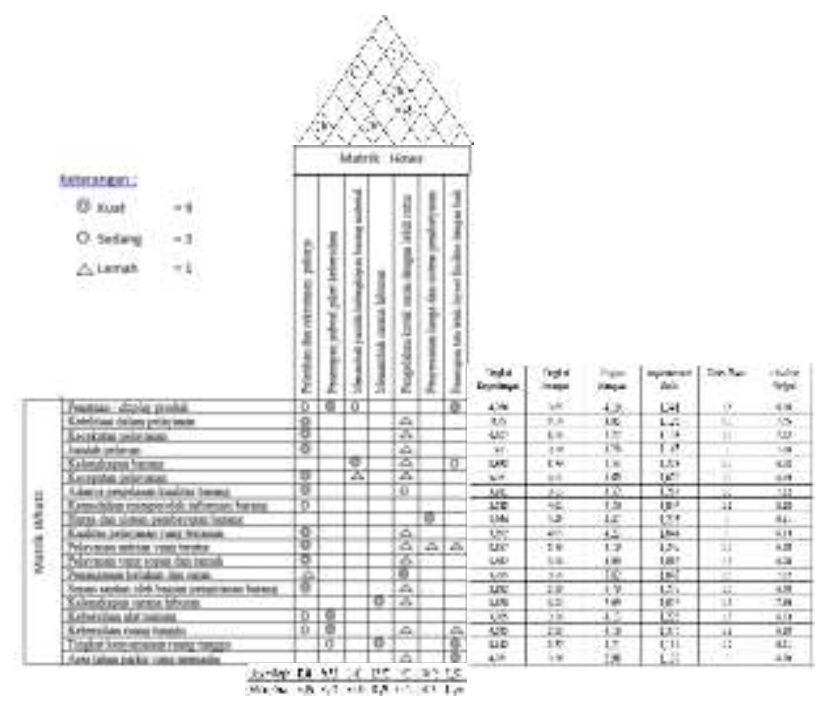

Gambar 9 House of Quality

Dari model HOQ tersebut dapat dilihat mana respon teknis yang memiliki bobot terbesar.

Tabel 2 Peringkat Respon Teknis

\begin{tabular}{|c|l|c|c|}
\hline No & \multicolumn{1}{|c|}{ Reson Teknis } & $\begin{array}{c}\text { Nilai Rar Weight } \\
\text { and Percent }\end{array}$ & Peringkat \\
\hline 1 & $\begin{array}{l}\text { Pelatihan dan rekentmen pekerja } \\
\text { yang tepat }\end{array}$ & 77,329 & 5 \\
\hline 2 & $\begin{array}{l}\text { Penerapan jadwal piket } \\
\text { kebersihan bagi setiap pekerja }\end{array}$ & 84,666 & 4 \\
\hline 3 & $\begin{array}{l}\text { Menambah jumlah dan } \\
\text { keiengkapan barang material }\end{array}$ & 163,200 & 1 \\
\hline 4 & $\begin{array}{l}\text { Menambah sarana hiburan } \\
\text { seperti musik dan tv }\end{array}$ & 140,232 & 2 \\
\hline 5 & $\begin{array}{l}\text { Pengolahan kotak saran yang } \\
\text { dilakukan lebih nutin }\end{array}$ & 64,452 & 6 \\
\hline 6 & $\begin{array}{l}\text { Penvesuaian harga dan sistem } \\
\text { pembayaran barang material }\end{array}$ & 60,290 & 7 \\
\hline 7 & $\begin{array}{l}\text { Penerapan tata letak lapout } \\
\text { fasilitas yarg lebih baik }\end{array}$ & 124,693 & 3 \\
\hline
\end{tabular}

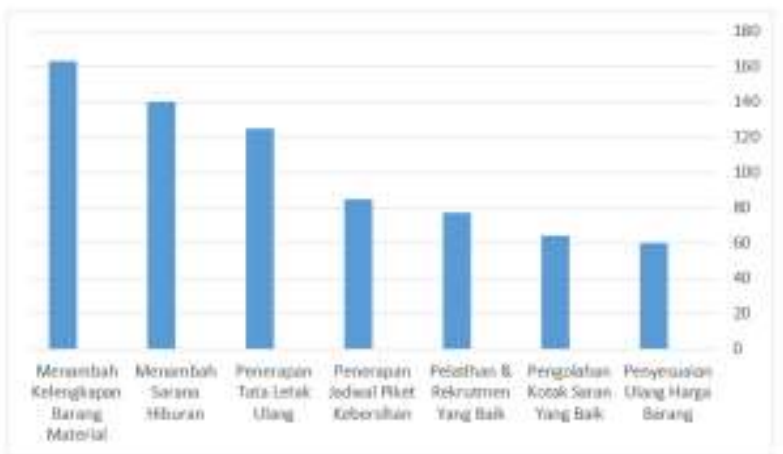

Gambar 10 Diagram Batang Respon Teknis

Pada HOQ, respon teknis memiliki peran penting dalam memenuhi kebutuhan konsumen. Berdasarkan korelasi antar matriks Whats dan matriks Hows, maka dapat diketahui respon teknis manakah yang penting. Respon teknis yang paling penting berdasarkan pada HOQ adalah pada Menambah jumlah kelengkapan barang material dengan nilai 163,200. Dengan nilai yang tinggi, maka apabila respon teknis ini diterapkan oleh piha UD. Sumber Wangi maka dapat meningkatkan kepuasan konsumen dengan efektif. Selanjutnya respon teknis yang berada pada peringkat ke 2 adalah menambah sarana hiburan dengan nilai 140,232. Sedangkan respon teknis dengan nilai terendah adalah pada penyesuaian harga dan sistem pembayaran dengan nilai 60,290. Meskipon respon teknis ini memiliki nilai yang paling rendah, tapi apabila respon teknis ini diterapkan juga akan meningkatkan kepuasan pelanggan, namun tidak 
begitu signifikan dibandingkan dengan respon teknis yang memiliki nilai lebih tinggi.

\section{KESIMPULAN DAN SARAN}

\section{A. KESIMPULAN}

Berdasarkan hasil pada peneliitan ini, maka dapat diambil beberapa kesimpulan.

1. Teridentifikasi terdapat 28 atribut pelayanan yang dapat mempengaruhi tingkat kepuasan pelanggan. Atribut tersebut terdiri dari 7 atribut pelayanan pada dimensi reliability, 4 atribut layanan pada dimensi responsiveness, 7 atribut layanan pada dimensi assurance, 4 atribut layanan pada dimensi emphaty, dan 7 atribut layanan pada dimensi tangible.

2. Dari data kuesioner yang terdiri dari data tingkat kepuasan, tingkat kepentingan, dan tingkat harapan. Keseluruhan data tersebut telah di uji validitas dan reliabilitas, dan hasilnya keseluruhan data adalah valid dan reliabel.

3. Dari pengolahan data dengan konsep servqual, total dari ke 28 atribut layanan, terdapat 19 atribut layanan yang mengalami kesenjangan dan bernilai gap negatif. Atribut dengan nilai gap negatif inilah yang akan diteliti lebih lanjut pada pengolahan data dengan metode Quality Function Deployment.

4. Pada model HOQ, terdapat beberapa respon teknis yang harus ditingkatkan untuk memenuhi kepuasan pelanggan. Respon teknis ini terdapat 2 penilaian yang masing masing harus dipilih yang mana untuk ditingkatkan. Penilaian pertama adalam absolute weight yang merupakan penilaian berdasarkan tingkat kepentingan suatu voice of customer yang dikorelasikan dengan respon teknis yang berkaitan. Untuk nilai absolute weight tertinggi adalah pada penambahan jumlah barang material dengan skor tertinggi yakni 126,281. Sedangkan untuk Penilaian respon teknis terbaik adalah relative weight and percent yang merupakan korelasi matriks Whats dan matriks Hows. Respon teknis yang memilik skor tertinggi adalah penambahan sarana hiburan dengan nilai 140,232

\section{B. Saran}

\section{Saran Untuk Perusahaan}

Berdasarkan analisa akhir HOQ yakni pada respon teknis nya, maka dapat diberikan beberapa saran untuk UD. Sumbe Wangi.

1. Perusahaan sebaiknya perlu meningkatkan kelengkapan barang material karena memiliki skor tertinggi. Dengan meningkatkan sarana hiburan, maka secara tidak langsung perusahaan dapat meningkatkan atribut pelayanan atau suara pelanggan berupa kenyamanan ruang tunggu dan sarana hiburan ruang tunggu. Kedua atribut ini memiliki tingkat kepentingan tertinggi namun tingkat kepuasannya masih rendah. Sehingga dengan menambah sarana hiburan, maka pelanggan akan sangat meningkatkan kepuasan pelanggan.

2. Perusahaan juga perlu menanggapi respon teknis pada peringkat selanjutnya, karena respon teknis ini juga penting untuk memenuhi kebutuhan konsumen, tergantung pada nilai dan peringkat dari respon teknis itu. Semakin tinggi nilainya semakin besar pengaruhnya, dan sebaiknya segera diterapkan respon teknis tersebut.

\section{Saran Untuk Penelitian Selanjutnya}

Berdasarkan pengalaman pada penelitian ini, maka untuk penelitian selanjutnya dapat diberikan beberapa saran

1. Responden dalam mengisi kuesioner harus diberikan pemahaman mengenai masing masing atribut layanan, sehingga setiap responden memiliki persepsi yang sama mengenai pengertian dari setiap atribut pelayanan. Dengan begitu maka data yang didapat pasti valid dan reliabel,

2. Pengolahan data uji validitas dan reliabilitas sebaiknya menggunakan software komputer sehingga mempercepat penelitian dan tingkat kesalahan lebih rendah. Sementara bila dilakukan dengan penghitungan manual membutuhkan waktu yang sangat lama dan 
memiliki tingkat kesalahan perhitungan yang tinggi.

3. Pengolahan data pada metode QFD sebaiknya menggunakan bantuan software komputer sehingga dapat mempercepat penelitian dengan tingkat kesalahan perhitungan lebih rendah. Apabila dilakukan perhitungan satu persatu atau manual maka akan membutuhkan waktu lebih lama dengan tingkat kemungkinan kesalahan perhitungan yang tinggi.

\section{Daftar Pustaka}

Arief, M. 2016. Kualitas Pelayanan Publik Di Bandara Internasional Sultan Hasanuddin Makassar. Makassar, Universitas Negeri Makassar.

Destyasa, E.W., Setyanto, N.W., Farela, C. 2015. Analisis Kualitas Jasa Listrik Prabayar Dengan Mengintegrasikan Metode Service Quality (Servqual) Dan Quality Function Deployment (QFD). Malang : Universitas Brawijaya

Setyono, H. 2016. Penggunaan Uji Reliabilitas Dan Uji Validitas Sebagai Langkah Awal Pengolahan Data. Jakarta. Universitas Indonesia

Egi, M. 2016. Analisa Pelayanan Terpadu Pada Fasiitas Sekolah SDN Ketapang 2 Dengan Penerapan Metode Quality Function Deployment (QFD). Solo: Universitas Muhammadiyah Solo

Hartanti, F.T., Hariastuti, N.L.P. 2015. Integrasi Servqual Dan QFD Untuk Meningkatkan Kualitas Pelayanan Di Tempat Rekreasi Kenjeran Baru Surabaya. Surabaya : Institut Teknologi Adhi Tama Surabaya (ITATS

Junaedi, D., Puri, H. 2015. Evaluasi Kualitas Jasa Kepariwisataan Dengan Metode Servqual Dan QFD. Jakarta : Universitas Mercu Buana Jakarta

Margareta, P.A., Wahyuni, H.C. 2016. Peningkatan Kualitas Pelatihan Di Training
Centre Melalui Integrasi Metode Service Quality (Servqual) Dan Quality Function Deployment ( $Q F D)$. Sidoarjo : Universitas Muhammadiyah Sidoarjo

Priyanto, A.C. 2018. Pengaruh Kualitas Produk Dan Kualitas Layanan Terhadap Loyalitas Pelanggan Pada Usaha Isi Ulang Air Minum UD. Elangku Di Desa Bangunrejo Tenggarong Seberang. Samarinda : Universitas Mulawarman

Rahma,W., Ayu, N. 2017. Pengukuran Tingkat Kepuasan Pelanggan Pada Kantor Pos Kabupaten Pati Dengan Konsep Service Quality. Jepara : Universitas Semarang

Singarimbtun, M., Sofian, E. 1989. Metode Penelitian Survai. Jakarta : LP3ES

Wijaya, Tony. 2016. Manajemen Kualitas Jasa. Jakarta : Indeks

Hidayat, H., Jufriyanto, M., \& Rizqi, A. (2021). Perancangan RCM (Reliability Centered Maintenance) Untuk Mengurangi Downtime Mesin Pembuat Botol (Studi Kasus PT IGLAS (Persero), Gresik). MATRIK : Jurnal Manajemen Dan Teknik Industri Produksi, 21(2), 157 - 164. doi:10.30587/matrik.v21i2.2038

Hidayat, H. (2020). Application of the EOQ (Economic Order Quantity) Method in Determining Chemical Supplies in PT. Semen Indonesia. International Journal of Science, Engineering and Information Technology, 5(1), 226-230.

Hidayat, Jufriyanto, M., Wasiur, A., \& Ningtyas, A. H. P. (2020). Analysis Of Load Variations On ST 60 Steel Using Vickers Method. International Journal of Science, Engineering and Information Technology, 05(02), 5-9. https://doi.org/10.21107/ijseit.v5i1.8940 